\title{
Lactase Activity in Newborn and Infant Baganda
}

\author{
G. C. COOK,* M.D., B.SC., M.R.C.P.
}

In most Europeans jejunal lactase is present from the third month of gestation, reaches a peak at birth, and remains high throughout life (Auricchio et al., 1963b, 1965). After premature birth the lactase level rises independently of milk intake. Specific lactase deficiency in the newborn often produces symptoms after the first few feeds; it probably has a congenital hereditary basis (Holzel et al., 1959 ; Weijers et al., 1961 ; Launiala et al., 1966). Lactose accounts for almost $50 \%$ of the calorie value of breast milk. The level of milk intake does not seem to influence lactase activity. In a limited human study no enzyme adaptation occurred (Cuatrecasas et al., 1965) ; very little correlation between lactase activity and milk intake was found by Cook and Kajubi (1966). In several other mammalian species (Plimmer, 1906 ; Heilskov, 1951 ; Fischer, 1957) results are similar; if rats are fed a $25 \%$ lactose diet, lactase activity per unit weight of mucosa is not affected (Fischer, 1957). The very high lactase level in the newborn is not usually maintained into adult life ; only rarely, however, does the level fall low enough for symptoms of milk intolerance to appear (Auricchio et al., 1963a ; Haemmerli et al., 1965; McMichael, et al., 1965). The cause of specific lactase deficiency presenting first in adult life is not known with certainty. Some cases have a familial history (McMichael et al., 1965). It is common in some racial groups; a high incidence has been shown in the American Negro (Cuatrecasas et al., 1965 ; Rosensweig and Bayless, 1966), and the Baganda and other Bantu tribes of Uganda (Cook and Kajubi, 1966). It is probably also common in India (Jeejeebhoy et al., 1964) and in the Greek Cypriot (McMichael et al., 1966).

The present study is an investigation of lactase activity in the newborn and infant in a population in which specific lactase deficiency is very common in adult life.

\section{Newborn and Infants Studied}

Both parents of all subjects were of Baganda stock. The age, sex, and mean body weights of 72 subjects studied are shown in Table I. Eleven babies studied within 30 hours of birth had not been fed. Eleven studied within one week of birth had been fed, in all except one from the breast. Owing to uncertainty about exact age, other infants were divided into six-month groups during the first 2 years, 12-month groups between 2 and 5 years, and one two-year group between 7 and 9 years.

Sixty-two of the subjects, including all within the first week of life, were studied at Mulago Hospital, Kampala. Ten were investigated at a home for healthy babies (the Sanyu Home, Kampala). Eight of the newborn infants had had an abnormal delivery, though all were physically normal. There was a wide range of diagnoses in the infants at Mulago Hospital who were more than 1 week old. In no case was there clinical evidence of malnutrition or gastrointestinal disease, except in two infants of 1 and 2 months, who were found retrospectively to have had intermittent non-infective diarrhoea since birth. These two had recently lost weight. All others were gaining weight. The 10 infants studied at Sanyu were all clinically well. The

* Lecturer in Medicine, Makerere University College, Kampala, Uganda. From Mulago Hospital and the Medical Research Council Malnutrition Unit, Kampala, UIganda. diet and milk intake of some of the Mulago patients was difficult to assess accurately; most were taking small amounts of milk. The Sanyu infants were all receiving a good diet and up to $5 \mathrm{oz}$. (140 ml.) of milk per $\mathrm{kg}$. body weight per day; they had been at the home for $1 \frac{1}{2}$ to 21 (mean $7 \frac{1}{2}$ ) months. Four of the 10 had been poorly nourished on admission.

The mean body weights at all ages were slightly lower than those reported for Baganda by Rutishauser (1965); in the present study most values were 10 to $12 \%$ lower.

Specimens of proximal jejunal and the third or fourth part of duodenum were obtained immediately after death from four newborn Baganda. They were removed in each case within 20 minutes of death. The age, sex, birth weights, and diagnoses are shown in Table II.

\section{Methods}

Tolerance tests after oral lactose $(2 \mathrm{~g} . / \mathrm{kg}$. body weight) were performed in 72 newborn babies and infants after a six- or eight-hour fast. Lactose was given to the younger babies by polyethylene gastric tube. Capillary blood was obtained at $0,30,60,90,120$, and 150 minutes. Glucose and galactose tests ( $1 \mathrm{~g}$. glucose $+1 \mathrm{~g}$. galactose $/ \mathrm{kg}$. body weight) were performed within five days in 10 who had a maximum rise in glucose less than $20 \mathrm{mg} . / 100 \mathrm{ml}$. Oral carbohydrate was given as an approximately $12 \%(\mathrm{~W} / \mathrm{V})$ solution in water. Blood glucose was estimated by a glucose-oxidase method (Marks, 1959). Plasma protein and amino-acid ratio (Whitehead, 1964) were estimated in 13, and urinary hydroxyproline index (Whitehead, 1965) in seven. Stool $p \mathrm{H}$ was measured with $\mathrm{pH}$ paper. Specimens of jejunum obtained from the newborn after death were divided; part was immediately frozen to $-15^{\circ} \mathrm{C}$. and the remainder examined under the dissecting microscope in the fresh state. Assay of disaccharidases was carried out within seven days by the modification of the method of Dahlqvist (1964) described by Cook and Kajubi (1966); after thawing, mucosa was immediately separated from the muscle layer of the jejunum with a scalpel, washed, and homogenized in ice-cold saline solution.

\section{Results}

\section{Carbohydrate-tolerance Tests}

The mean fasting blood glucose and rise in glucose after lactose are summarized in Table $\mathrm{I}$. The mean rise in glucose was $44.3 \mathrm{mg} . / 100 \mathrm{ml}$. at birth and $63.1 \mathrm{mg} . / 100 \mathrm{ml}$. during the first week of life (see Chart) ; the difference is not significant $(P<0.1)$. The scatter of results is wide in all groups. A fall in mean values is shown with increasing age. The mean rise in glucose at birth is significantly higher than that at 6 to 11 months $(P<0.05), 12$ to 17 months $(P<0.02), 24$ to 35 months $(P<0.05), 36$ to 47 months $(P<0.01), 48$ to 60 months $(P<0.001)$, and 7 to 9 years $(P<0.001)$. In all groups after the first week of life one or more subjects had a maximum rise less than $20 \mathrm{mg}$. $/ 100 \mathrm{ml}$. In the 36-to-47-month, 48-to-60-month, and 7-to-9-year groups $60 \%, 100 \%$, and $100 \%$ of the results were below $20 \mathrm{mg} . / 100 \mathrm{ml}$. 
Four infants with a maximum rise of less than $20 \mathrm{mg} . / 100 \mathrm{ml}$. were breast-fed at the time of the test (see Chart). Five with a rise of less than $20 \mathrm{mg} . / 100 \mathrm{ml}$. were at the Sanyu Home, and were well nourished clinically and biochemically (see below); two others had been poorly nourished throughout their lives. Of the infants over 1 week old with a maximum rise in glucose over $20 \mathrm{mg} . / 100 \mathrm{ml}$. five were breast-fed. Five were at the Sanyu Home; two had been poorly nourished on admission four and 21 months previously.

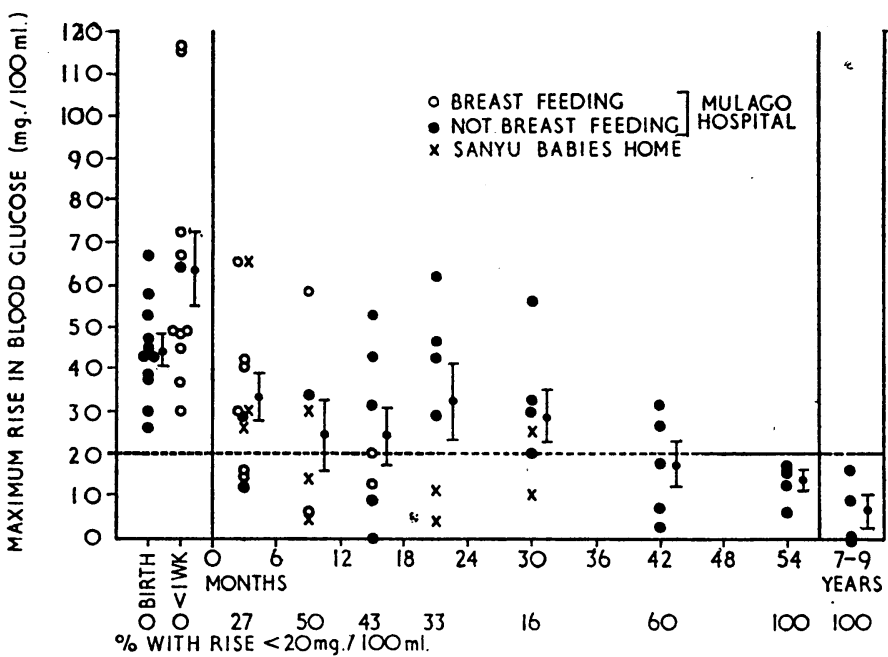

Results of lactose-tolerance tests. Maximum rise in blood glucose after oral lactose ( $2 \mathrm{~g} . / \mathrm{kg}$. body weight) in groups of newborn and infant Baganda after a two-and-a-half-hour tolerance test. (The broken line with normal and abnormal lactase activity.) Mean values \pm 1 S.D. of the mean are shown for each group.

Assessment of diarrhoea during and after the tests was difficult because of poor reporting. The two infants in the 0-to-5-month group who were losing weight had a rise in glucose of 12 and $14 \mathrm{mg} . / 100 \mathrm{ml}$. respectively. Both had diarrhoea. Stool $\mathrm{pH}$ was acid in the former, who subsequently died. A 3-year-old and two 8-year-old children with maximum rise in glucose of 3,1 , and $16 \mathrm{mg} . / 100 \mathrm{ml}$. respectively had diarrhoea during the test; stool pH in two cases was acid.
Glucose-galactose tests were performed in 10 who had had a rise in glucose after lactose below $20 \mathrm{mg} . / 100 \mathrm{ml}$. (Table I). In all, the ratio of maximum rise in glucose after lactose to that after glucose and galactose was less than 0.60 , in eight less than 0.50 , and in six less than 0.40 ; no subject had diarrhoea. In most, including the newborn, the lactosetolerance curve showed a rapid rise to 30 or 60 minutes, followed by a steady fall. A few showed later peak levels; one at birth and five in the first week had a maximum level at 90 minutes. Four others had a peak at 90 minutes, and 11 (eight of whom had a maximum rise of less than $20 \mathrm{mg}$./ $100 \mathrm{ml}$.) at 120 or 150 minutes. In all except three the maximum rise after glucose and galactose was at 30 or 60 minutes.

\section{Biochemical Tests of Nutritional Status}

Nine infants from the Sanyu Home and four from Mulago Hospital had plasma proteins and amino-acid ratios estimated. All except one of the Sanyu babies had normal values: plasma protein 6.6 to 8.2 (mean 7.6 ) g. $/ 100 \mathrm{ml}$; amino-acid ratio 1.1. to 2.0 (mean 1.5) (normal range <3.0). Two of the Mulago subjects had low values: plasma protein 4.2 to 7.8 (mean 6.6) g. $/ 100 \mathrm{ml}$; amino-acid ratio 1.8 to 4.0 (mean 2.7). A hydroxyproline index was done on six patients from the Sanyu Home and one from Mulago Hospital. All except one of the former were normal, 1.4 to 2.6 (mean 2.2) (normal range 2.0 to 5.0) ; the Mulago patient had a value of 1.5 . The Mulago infants who had the tests done had a maximum glucose rise: after lactose of $33,20,6$, and $58 \mathrm{mg} . / 100 \mathrm{ml}$. respectively.

\section{Jejunal Disaccharidase Estimations}

Four newborn babies were studied (Table II). In each case dissecting microscopy showed predominantly tall, pointed, finger-shaped villi in the jejunum; in three there were leafshaped villi also. The duodenum consisted of leaf-shaped villi with short ridges. In each case all disaccharidase levelslactase, sucrase, maltase, isomaltase (palatinase), and trehalase -were similar to or higher than in European and American adults (Auricchio et al., 1963a ; Dahlqvist et al., 1963 ; Plotkin and Isselbacher, 1964 ; Dunphy et al., 1965 ; Haemmerli et al.s.

Table I.-Sex, Mean Body Weight, and Results of Carbohydrate Tolerance Tests in the Newborn and Infants Studied

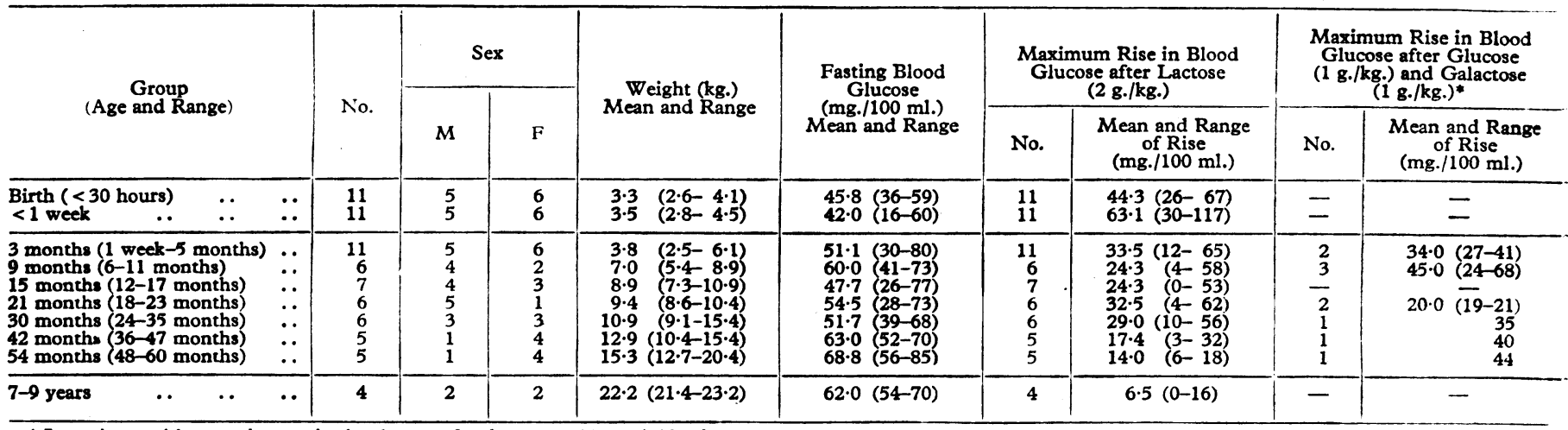

- In patients with a maximum rise in glucose after lactose $<20 \mathrm{mg} . / 100 \mathrm{ml}$.

TABLE II.-Sex, Birth Weights, Diagnoses, and fejunal Disaccharidase Levels in Newborn Baganda

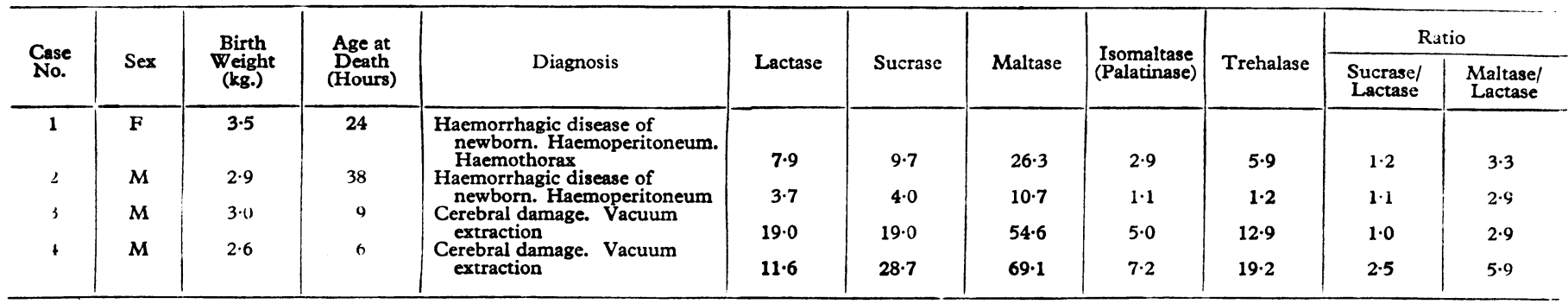


1965 ; Sheehy and Anderson, 1965 ; McMichael et al., 1966) (Table II). Lactase levels were very much higher than in adult Baganda (Cook and Kajubi, 1966). All disaccharidase levels in the duodenum were 10 to $20 \%$ lower than in the jejunum; the ratios were in all cases very similar to those in the jejunum.

\section{Discussion}

The Baganda tribe has a very high incidence of specific lactase deficiency in adult life. Jejunal lactase and other disaccharidases at birth have been shown to be high and comparable to European levels. The functional presence of lactase in the newborn has been confirmed by lactose tolerance. The rate of decline in lactase activity between birth and adult life has been followed by lactose tolerance ; a large number of jejunal biopsies in the newborn and infants was not considered justifiable. A small percentage of subjects with normal lactase have "flat" lactose-tolerance curves (Newcomer and McGill, 1966), but most workers believe the test to be of value (Dunphy et al., 1965 ; McMichael et al., 1965 ; Peternel, 1965 ; Sheehy and Anderson, 1965 ; Cook and Kajubi, 1966). The normal lactase levels reported by Newcomer and McGill (1966) were lower than those given by most authors. Though gastric emptying is usually slow in the newborn (Smith, 1959), this was not the case in the present study ; a rapid rise in glucose to a peak at 30 or 60 minutes, with a rapid fall, was usually seen after lactose. The test used was always continued for two and a half hours. Passage of food from stomach to caecum in the newborn takes from three to six hours (Smith, 1959). It is unlikely that a "peak" value was often missed on account of slow passage through the small intestine; the glucose-galactose test usually gave an early high maximum in the infants with "flat" lactose curves.

The fall with age in maximum glucose after lactose shown in this study probably reflects a true fall in lactase; most become deficient between 3 and 4 years, though others have low levels during the first six months. Whether the fall is due to a specific loss of lactase has not been definitely established; other disaccharidases have not been investigated. The gradual fall from birth and previous demonstration of a specific deficiency in the adult suggest that it is. A normal rise in glucose after glucose and galactose makes it unlikely that there was severe mucosal damage (Holdsworth and Dawson, 1965). It is unlikely that sucrose- and maltose-tolerance tests would have been of value, as sucrase and maltase are always present in much higher concentration than lactase. Nonspecific secondary disaccharidase deficiency is common in infancy and childhood owing to infections (Sunshine and Kretchmer, 1964 ; Anderson et al., 1966) and malnutrition (Bowie et al., 1963, 1965 ; Stanfield et al., 1965). Though it is possible that either of these was responsible for low lactase levels in some, these were probably not major factors. Only two of the patients studied had diarrhoea before the tests. Biochemical tests indicated that some of the Mulago subjects were mildly malnourished; 5 of the 10 infants at the Sanyu Home who were clinically and biochemically well nourished had flat lactose curves.

The cause of the fall in lactase activity is uncertain. Nutritional status seems unlikely. Absence of milk in the diet is also unlikely ; some infants with flat curves were breast-fed, and most of the Sanyu infants had had milk for many weeks before the tests. These results, together with the tribal difference between the Baganda and other tribes in Uganda (Cook and Kajubi, 1966), suggest a genetic basis for the fall in lactase early in life analogous to that seen in the cow, guinea-pig, pig, rabbit, and rat (Plimmer, 1906 ; Heilskov, 1951; Bailey et al., 1956 ; Herzenberg and Herzenberg, 1959 ; Dahlqvist, 1961, 1962 ; Doell and Kretchmer, 1962 ; Rubino et al., 1964 ; Sterk and Kretchmer, 1964). If lactose is given to the weanling pig whose lactase is falling, diarrhoea and failure to thrive result
(Becker and Terrill, 1954). Only five of the cases here studied showed definite clinical evidence of disaccharide intolerance (Anderson et al., 1966), though recording of the frequency of diarrhoea was not always reliable. Diarrhoea is common after lactose in healthy Baganda adults (Cook and Kajubi, 1966), and the present study suggests that many cases of lactose intolerance probably exist among infant Baganda. Fall in lactase is not uniform in this population; an early fall in activity is likely in some during the breast-feeding period. Lactose intolerance must be carefully looked for in malnourished, especially marasmic, infants. A very high incidence of infant malnutrition exists in the Baganda ; lactose intolerance may be an important cause. The growth rate of Baganda infants is good during the first six months, after which the growth curve slackens (Trowell, 1960 ; Rutishauser, 1965) and cases of marasmus appear. Diarrhoea and failure to thrive in infancy appear to run parallel in the South African Bantu (Wittmann and Hansen, 1965). Lactose intolerance could be an additional factor in other forms of protein-calorie malnutrition; children in the same family often become severely malnourished, while others thrive (Trowell, 1960). The child with hypolactasia may be left on a "knife-edge" at weaning.

\section{Summary}

Normal levels of disaccharidases, including lactase, were found in the jejunum of four newborn Baganda infants immediately after death.

Lactose-tolerance tests were carried out in 72 Baganda newborn and infants; a gradual fall in mean maximum rise in glucose was shown during the first four years of life. Some cases of hypolactasia appeared as early as the first six months. Glucose-galactose tolerance tests were performed in 10 subjects with a flat curve after lactose; maximum rise in glucose was higher in all.

Amino-acid ratio was estimated in 13 and hydroxyproline index in seven subjects.

Fall in lactase activity does not seem to be related to malnutrition, gastrointestinal infection, or milk intake ; it is probably a genetically determined defect which becomes overt early in life.

The probable importance of this enzyme defect in the pathogenesis of infant malnutrition is discussed.

I thank Dr. J. A. Kagwa and Dr. J. P. Stanfield for allowing me to study patients under their care; the Board of Governors and the Superintendent, Mrs. F. A. K. Mulira, of the Sanyu Babies Home, Kampala, for their willing co-operation; and the many nurses who gave expert help with the babies. I am grateful to Dr. R. G. Whitehead for the plasma proteins, animo-acid ratios, and hydroxyproline indices, and to Professor R. A. McCance for his criticism of the manuscript. I acknowledge with thanks financial assistance provided by the Makerere University College Research Fund.

\section{REFERENCES}

Anderson, C. M., Burke, V., Messer, M., and Kerry, K. R. (1966). Lancet, 1, 1322

Auricchio, S., Rubino, A., Landolt, M., Semenza, G., and Prader, A. (1963a). 'Ibid., 2, 324

Rubino, A., and Mürset, G. (1965). Pediatrics, 35, 944

Tosi, R., Semenza, G., Landolt, M., Kistler, H., and Prader, A. (1963b). Enzym. biol. clin. (Basel), 3, 193.

Bailey, C. B., Kitts, W. D., and Wood, A. J. (1956). Canad. F. agric. Sci., 36, 51 .

Becker, D. E., and Terrill, S. W. (1954). Arch. Biochem., 50, 399.

Bowie, M. D., Brinkman, G. L., and Hansen, J. D. L. (1963). Lancet, 2, 550 .

Cook, G. C. (1965). 7. Pediat., 66, 1083.

Cuatrecasas, P., Lockwood, D. H., and Caldwell, J. R. (1965). Ibid., 1, 14.

Dahlqvist, A. (1961). Nature (Lond.), 190, 31.

(1962). 于. clin. Invest., 41, 463 .

(1964). Analyt. Biochem., 7, 18.

Hammond, J. B., Crane, R. K., Dunphy, I. V.. and Littman, A.

(1963). Gastroenterology, 45, 488 . 
Doell, R. G., and Kretchmer, N. (1962). Biochim. biophys. Acta (Amst.), 62, 353 .

Dunphy, J. V., Littman, A., Hammond, J. B., Forstner, G., Dahlqvist, A., and Crane, R. K. (1965). Gastroenterology, 49, 12.

Fischer, J. E. (1957). Amer. F. P Pysiol., 188, 49

Haemmerli, U. P., Kistler, H., Ammann, R., Marthaler, T., Semenza, G., Auricchio, S., and Prader, A. (1965). Amer. 7. Med., 38, 7.

Heilskov, N. S. C. (1951). Acta physiol. scand., 24, 84.

Herzenberg, L. A., and Herzenberg, L. A. (1959). Nutr. Rev., 17, 65.

Herzenberg, L. A., and Herzenberg, L. A. (1959). Nutr. Rev,

Holdsworth, C. D., and Dawson, A. M. (1965). Gut, 6, 387. $1,1126$.

Jeejeebhoy, K. N., Desai, H. G., and Verghese, R. V. (1964). Ibid., 2, 666.

Launiala, K., Kuitunen, P., and Visakorpi, J. K. (1966). Acta paediat. (Uppsala), 55, 257.

McMichael, H. B., Webb, J., and Dawson, A. M. (1965). Lancet, 1, 717.

Tars (1966). Brit. med. 7., 2, 1037.

Newcomer, A D. Clin. chim. Acta, 4, 395. Gastroenterology, 50, 340

Peternel, W. W. (1965). Ibid., 48, 299.
Plimmer, R. H. A. (1906). 7. Physiol. (Lond.), 35, 20.

Plotkin, G. R., and Isselbacher, K. J. (1964). New Engl. F. Med., 271, 1033.

Rosensweig, N. S., and Bayless, T. M. (1966). f. clin. Invest., 45, 1064. Rubino, A., Zimbalatti, F., and Auricchio, S. (1964). Biochim. biophys. Acta (Amst.), 92, 305.

Rutishauser, I. H. E. (1965). Lancet, 2, 565.

Sheehy, T W. and Anderson, P. R. (1965). Ibid., 2, 1.

Smith, C. A. (1959). The Physiology of the Newborn Infant, 3rd ed., p. 232, 235. Oxford.

Stanfield, J. P., Hutt, M. S. R., and Tunnicliffe, R. (1965). Lancet, 2, 519.

Sterk, V V., and Kretchmer, N (1964). Pediatrics, 34, 609.

Sunshine, P., and Kretchmer, N. (1964). Ibid., 34, 38.

Trowell, H."C. (1960). Non-infective Disease in Africa, pp. 331, 350. London.

Weijers, H. A., Van De Kamer, J. H., Dicke, W. K., and Ijsseling, J. (1961). Acta paediat. (Uppsala), 50, 55 .

Whitehead, R. G. (1964). Lancet, 1, 250.

- (1965). Ibid., 2, 567.

Wittmann, W., and Hansen, J. D. L. (1965). S. Afr. med. F., 39, 223.

\title{
Field Studies of Human Stress in Polar Regions
}

\author{
H. W. SIMPSON,* M.D., PH.D.
}

Brit. med. F., 1967, 1, 530-533

Why do explorers explore? The polar epics are a series of desperate situations-crevasses, starvation, cold, crushed ships, and so on. Do these "stress" the participants or are they comparatively unaffected because of a different constitution ? The term "stress" is used here to indicate any situation adverse to man associated with adrenocortical hyperactivity.

This study is an objective assessment of possible stress situations in Antarctic and Arctic regions; two indices of adrenocortical function-(1) the venous blood eosinophil count and (2) the urinary output of 17-hydroxycorticosteroids (17-OHCS) -were used.

The field work was carried out while I was a medical officer with the British Antarctic Survey and during a small expedition which skied 400 miles $(640 \mathrm{~km}$.) across the Greenland ice-cap.

\section{Methods}

Venous blood eosinophils were counted at once by the direct method of Thorn, Forsham, Prunty, and Hills (1948). Retrospective analysis of eosinophil scatter in the chambers showed almost perfect Poisson distribution (see Berkson, Magath, and Hurn, 1940). This indicates a satisfactory technique in spite of working in the field. For more details see Simpson (1959).

Total 17-OHCS were measured by a modification of Norymberski's technique (Appleby, Gibson, Norymberski, and Stubbs, 1955). Complete urine collections were made each day in polyethylene containers, the volume was recorded, and an 8-ml. aliquot taken. These small specimens, unpreserved, were then brought back to Glasgow for analysis. The storage qualities of these corticosteroid metabolites have already been investigated and found excellent (Simpson, 1965a, 1965b).

\section{Short-term Stress (One to Two Days)}

One man was studied over a period of two months at the base hut by making counts on alternate days. The object of this was to have a continuous tracing of eosinophil counts over a fairly long period and thus obtain a complete record of any

\footnotetext{
* University Department of Pathology, Royal Infirmary, Glasgow.
}

sudden unexpected events, which are always a possibility in Antarctica. The results are seen in Table I.

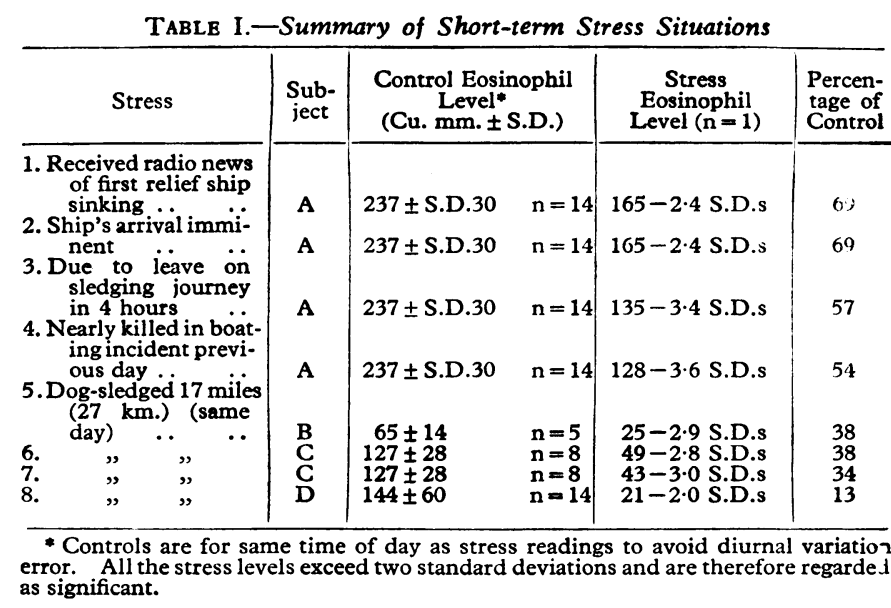

In stress 1 the relief ship was holed after hitting an ice floe and had to send out an S O S when the front hold filled with water. Boats were lowered. Later the master found that by going astern the leak was less serious and the pumps were gaining. All the base's mail, etc., was on board. This was the first ship for eight months.

In stress 4 an Argentine N.C.O. from an adjacent foreign base was being swept out to sea in a rowing-boat by the prevailing current. His outboard motor had run out of petrol and he lost the oars in the ensuing panic. Already one man had been killed in an identical manner the previous year, and as the weather was deteriorating the situation was desperate. This subject (A), with three companions, had put out to sea in a disused and leaky British rowing-boat in an attempt to reach the man, but after struggling for four hours they had to give up the attempt and only just managed to return, as by then a wind of gale force was blowing off shore. Fortunately the man was rescued later when a helicopter from an icebreaker spotted him 25 miles $(40 \mathrm{~km}$.) out.

Other opportunities for studying stress at the main base came with the arrival of dog-sledge parties returning from field work. 